\title{
Effect of crude glycerol on in-vitro ruminal fermentation kinetics
}

\author{
Efeito do glicerol sobre a cinética da fermentação in vitro
}

\author{
PERIPOLLI, Vanessa ${ }^{1 *}$; PRATES, Ênio Rosa ${ }^{1}$; BARCELLOS, Júlio Otávio Jardim ${ }^{1}$; \\ WILBERT, Cássio André ${ }^{2}$; CAMARGO, Cláudia Medeiros ${ }^{3}$; LOPES, Rúbia Branco ${ }^{1}$; \\ COSTA Junior, João Batista Gonçalves ${ }^{1}$
}

\author{
${ }^{1}$ Universidade Federal do Rio Grande do Sul, Faculdade de Agronomia, Departamento de Zootecnia, \\ Porto Alegre, Rio Grande do Sul, Brasil. \\ ${ }^{2}$ Embrapa Suínos e Aves, Concórdia, Santa Catarina, Brasil. \\ ${ }^{3}$ Universidade Federal de Pelotas, Departamento de Tecnologia e Ciências de Alimentos, Pelotas, Rio \\ Grande do Sul, Brasil. \\ *Endereço para correspondência: vanessa.peripolli@hotmail.com
}

\section{SUMMARY}

The interest in using crude glycerol in animal feeding has reemerged due to its increasing availability and favorable price resulting from the expansion of biofuel industry. The objective of the present study was to evaluate the effects of substituting corn for crude glycerol at different levels in the diet on ruminal fermentation using in-vitro true digestibility parameters. The experimental treatments consisted of substituting corn for liquid crude glycerol $(0 ; 4 ; 8$ and $12 \%)$ in dry matter basis. Diets consisted of $60 \%$ alfalfa hay and $40 \%$ corn and glycerol substituted the corn in the diet. In addition to the 48 hours traditionally applied in digestibility assays, different in-vitro digestibility times were used $(0 ; 4 ; 8 ; 16 ; 48,72$ and 96 hours) in order to study digestion kinetics. The dietary corn substitution for increasing crude glycerol levels did not affect ammonia nitrogen content, metabolizable energy content, in-vitro digestibility of organic matter and neutral detergent fiber, nor ruminal degradation parameters. However this byproduct of biodiesel production may be tested in-vivo as an alternative energy feedstuff in ruminant diets.

Keywords: co-product of biodiesel, degradation parameters, effective degradability, in-vitro neutral detergent fiber digestibility, ruminant

\section{RESUMO}

O interesse na utilização da glicerina bruta na alimentação animal ressurge, devido ao aumento na disponibilidade e preço favorável, como conseqüência da expansão das indústrias de biocombustíveis. O objetivo deste trabalho foi avaliar os efeitos da substituição do milho por diferentes níveis de glicerina bruta na dieta sobre a fermentação ruminal através da digestibilidade in vitro verdadeira. As dietas experimentais consistiram na substituição do milho por glicerol $(0 ; 4 ; 8$ e $12 \%)$ na matéria seca da dieta (MS). As dietas eram compostas por $60 \%$ de feno de alfafa e $40 \%$ de grão de milho e o glicerol foi adicionado, substituindo o milho nas dietas. Além de trabalhar com as 48 horas tradicionais, foram utilizados diferentes horários de digestibilidade in vitro $(0 ; 4 ; 8 ; 16$; 48; 72 e 96 horas), com a finalidade de estudar a cinética da digestão. A substituição do milho por níveis crescente de glicerina bruta na dieta não afetou a concentração de $\mathrm{N}-\mathrm{NH}_{3}$, o teor de energia metabolizável, as digestibilidades in vitro da matéria orgânica da fibra em detergente neutro, bem como os parâmetros da degradação ruminal. Portanto, esse subproduto da produção do biodiesel deve ser testado in vivo como uma alternativa energética na formulação de dietas para ruminantes.

Palavras-chave: co-produto do biodiesel, degradabilidade efetiva, digestibilidade in vitro da fibra em detergente neutro, parâmetros de degradação, ruminantes 


\section{INTRODUCTION}

As ruminant production systems have become increasingly intensified, economic assessment related to feeding became critical, as feed accounts for 30 to $70 \%$ of total production costs depending on activity and type of operation (RESTLE et al., 2007; RODRIGUES \& RONDINA, 2013) reducing the profit margin for producers (GOES et al., 2008). Energy is the most expensive component of ruminant diets and its price has been influenced due to use of corn, soybean, and other grains for ethanol and biodiesel production. Also, oil price has risen due to growth of global population and income in countries whose economies grew at a faster rate. In this context, there has been an increasing number on the use of renewable energy sources due to rise in oil prices caused by the possible exhaustion of fossil energy reserves couples with concerns on global climate changes.

Among the renewable energy sources, biodiesel production has received much attention. Brazil has a great potential for the production of biofuels. In addition to planting several oil seeds that can be used for biodiesel production, it has cutting-edge technology and industrial capacity to develop it (OLIVEIRA et al., 2008).

Crude glycerol is the main by-product generated from biodiesel production: approximately 100 milliliters of crude glycerol are produced from each liter of biodiesel (THOMPSON \& HE, 2006). There are several industrial applications of purified crude glycerol, such as in cosmetics, pharmaceuticals and food industries. However, the degree of purity required for these applications demands complex and expensive processes, as crude glycerol contains impurities, such as water, oil, catalyzer, reagent residues, ethanol or methanol, propanediol and minerals (SOARES et al., 2010).

On the other hand, crude glycerol could be used as an alternative energy source for ruminant feeding, due to its increasing availability and favorable price as a result of the expansion of the biofuel industry, as well as increase in grain prices. Nevertheless, adequate inclusion levels, the impact and level of contaminants and the nutritional value of crude glycerol need to be determined in order to prevent intoxication or reduction of the efficiency of utilization of other dietary components.

The objective of this study was to evaluate in vitro digestibility and ruminal fermentation kinetics of substituting corn for different levels of crude glycerol in diets consisting of alfalfa hay and ground corn.

\section{MATERIALS AND METHODS}

The experiment was carried in the ruminant sector of Laboratory of Animal Science and the chemical analyses were performed at the Animal Nutrition Laboratory, both belonging to the Department of Animal Science of the School of Agronomy of the Federal University of Rio Grande do Sul.

Two Texel sheep, with $40 \mathrm{~kg}$ average body weight ruminally cannulated, were used as inoculum donor. The animals were kept in a $120 \mathrm{~m}^{2}$ paddock with a shelter during the entire experiment. Alfalfa hay $(88.51 \%$ dry matter, $88.32 \%$ organic matter, $19.20 \%$ crude protein, $54.45 \%$ neutral detergent fiber, and $30.64 \%$ acid detergent fiber) was fed at $3 \%$ body weight twice daily (8:00 AM and 5:00 PM). Mineral salt (13.2\% calcium, $8.0 \%$ phosphorus, $1.8 \%$ sulphur, $14.7 \%$ sodium, $0.13 \%$ manganese; $0.27 \%$ 
zinc; $0.0044 \%$ cobalt; $0.0088 \%$ iodine; $0.0018 \%$ selenium and $0.0800 \%$ fluorine) and water were supplied ad libitum. Before the experiment started, the animals were subjected to a 10 day adaptation period to the above described diet. The experimental protocol followed the guidelines of the Ethics Committee on the Use of Animals in
Research as Number 18.442 in compliance with Law 11.794.

The experimental treatments consisted of substituting corn for liquid crude glycerol $(0,4,8$ and $12 \%)$ in dry matter basis. Alfalfa hay (Medicago sativa) was used as roughage and comprised $60 \%$ of the diet. Table 1 shows the nutritional composition of the ingredients of the experimental diets.

Table 1. Dry matter $(\mathrm{DM})$, organic matter $(\mathrm{OM})$, crude protein $(\mathrm{CP})$, neutral detergent fiber (NDF), acid detergent fiber (ADF), crude energy (CE) and glycerol contents of the ingredients in the experimental diets

\begin{tabular}{|c|c|c|c|c|c|c|c|}
\hline \multirow{2}{*}{ Ingredients } & $\mathrm{DM}$ & $\mathrm{OM}$ & $\mathrm{CP}$ & NDF & $\mathrm{ADF}$ & \multirow{2}{*}{$\begin{array}{c}\mathrm{CE} \\
(\mathrm{MJ} / \mathrm{kg})\end{array}$} & \multirow{2}{*}{$\begin{array}{c}\text { Glycerol } \\
(\%)\end{array}$} \\
\hline & $(\%)$ & \multicolumn{4}{|c|}{$\% \mathrm{DM}$} & & \\
\hline Alfalfa hay & 88.51 & 88.32 & 19.20 & 54.45 & 30.64 & 18.67 & - \\
\hline Ground corn & 88.89 & 99.11 & 8.53 & 16.06 & 3.46 & 18.77 & - \\
\hline Crude glycerol* & 81.44 & . & 0.11 & - & - & 14.53 & 80.00 \\
\hline
\end{tabular}

*Methanol content lower than $45 \mathrm{mg} / \mathrm{L}$.

In-vitro true digestibility was determined according to Goering \& Van Soest (1970); however, in addition to the 48 hours traditionally used, digestibility was also determined at different times $(0 ; 4 ; 8 ; 16 ; 48 ; 72$ and 96 hours) aiming at studying the digestion kinetics of the different treatments.

One day before the incubation, in each $120 \mathrm{ml}$ fermentation flask, 0.5 grams of a sample consisting of the experimental treatments was placed, and the flasks were then kept in an oven at $39^{\circ} \mathrm{C}$. On incubation day, two hours after the animals received the morning meal, ruminal fluid was collected and kept in a thermos bottle at $39^{\circ} \mathrm{C}$, filtered through four gauze layers, and kept in a water bath to maintain temperature close to $39^{\circ} \mathrm{C}$. The ruminal fluid was mixed with artificial saliva (McDOUGALL, 1948), which was kept in water bath at $39^{\circ} \mathrm{C}$ and saturated with $\mathrm{CO}_{2}$, at a ratio of 1 part of ruminal fluid to 4 parts of artificial saliva. The mixture was homogenized in water bath and saturated with $\mathrm{CO}_{2}$.

Subsequently, $50 \mathrm{ml}$ of the mixture containing the culture medium and the ruminal fluid were added to each of fermentation flasks containing the different treatments, saturated with $\mathrm{CO}_{2}$ for about 30 seconds, rapidly closed with a rubber stopper with Bunsen valve and place in the incubator. The incubator was opened to agitate the flasks, three times per day, at 08:00, 12:00 and 17:00 hours. This procedure was carried out as quickly as possible to avoid drop of temperature.

Eight flasks (4 treatments and 2 replicate) were removed from the incubator at $0 ; 4 ; 8 ; 16 ; 48 ; 72$ and 96 hours of incubation and were placed in iced water to interrupt microorganism activity. Flasks were then immediately centrifuged at $10.000 \mathrm{rpm}$ for $10 \mathrm{~min}$, the supernatant was removed, and $100 \mathrm{ml}$ of neutral detergent solution 
were then added, following the method of Van Soest \& Robertson (1985). Flasks were sealed with aluminum foil and placed in a forced-circulation oven at $90^{\circ} \mathrm{C}$ for 16 hours, according to the technique proposed by Chai \& Udén (1998). The flask content was then filtered in sinterized glass crucible with coarse pore diameter. The crucibles with the residue were placed in an oven at $105^{\circ} \mathrm{C}$ for 12 hours, and weighed in order to obtain moisture-free residue weight, and later placed in the oven at $450^{\circ} \mathrm{C}$ for 5 hours.

The in-vitro organic matter true digestibility (IVOMTD) was calculated as the difference between the incubated organic matter (OM) and the nondigested OM, considered as the residue remaining in the crucibles. In-vitro neutral detergent fiber digestibility (IVNDFD) was calculated as the difference between incubated NDF and non-digested NDF, considered as the residue remaining in the crucibles after filtration and drying in the oven at $105^{\circ} \mathrm{C}$.

After the flasks were removed from the incubator and centrifuged, and before the neutral detergent solution was added, $20 \mathrm{ml}$ samples of the supernatant were removed for analysis of ammonia nitrogen $\left(\mathrm{NH}_{3}-\mathrm{N}\right)$. The concentration of $\mathrm{NH}_{3}-\mathrm{N}$ was determined by distillation with magnesium oxide (PRATES, 2007).

In order to study the kinetics of ruminal degradability, IVOMTD results obtained at the different times were subjected to the model of McDonald (1981), as follows: $Y_{t}=a+b\left(1-e^{-c(t-t o)}\right)$, where $Y_{t}=$ degradation after $t$ hours; $a$ $=$ substrate solubilized immediately; $\mathrm{b}=$ insoluble, but potentially degradable material; $\mathrm{a}+\mathrm{b}=$ potential degradability; $c=$ degradation rate of $b$; to $=$ lag time. The same model was used to obtain NDF degradation parameters, but the "a" parameter was excluded due to the absence of NDF solubilized immediately. Effective degradability (ED) was calculated using the equation proposed by McDonald (1981): ED = a $+[(\mathrm{b} \times \mathrm{c}) /(\mathrm{c}+\mathrm{k})] \mathrm{e}^{(\mathrm{c}+\mathrm{k}) \mathrm{t}}$, where $\mathrm{a}, \mathrm{b}$, and $\mathrm{c}$ follow the previous definitions, and $\mathrm{k}$ $=$ feed passage rate of 2 or $5 \% / \mathrm{h}$. The same model was used to calculate ED of NDF but the parameter "a" was excluded from the model.

The experiment was replicated in three runs with two duplicates within runs (56 treatment flasks corresponding to seven different times, 4 level of glycerol substitution and 2 duplicates plus 4 blanks flasks in each run).

Samples of the incubated feedstuffs (alfalfa hay and ground corn) were ground and analyzed for dry matter, organic matter and crude protein (PRATES, 2007). Neutral detergent fiber and acid detergent fiber were determined using a fiber analyzer (ANKOM's Fiber Analyzer Ankom ${ }^{\circledR}$ ) as described by Prates (2007). The enzyme alpha-amylase was used to determine NDF. Crude energy expressed in $\mathrm{MJ} / \mathrm{kg}$ dry matter, were determined in duplicate using an isoperibol calorimeter bomb (IKA ${ }^{\circledR}$ calorimeter C 2000). The analyses aforementioned were performed in triplicate. The nutritional composition of crude glycerol and its contamination with methanol were evaluated by a specialized laboratory (CBO Análises Laboratoriais, Campinas, SP).

A metabolizable energy (ME), expressed in $\mathrm{MJ} / \mathrm{kg}$ dry matter, was estimated considering the organic matter degradability (OMDeg) values obtained by the above mentioned technique and applied to the equation proposed by Menke \& Steingass (1988), where $\mathrm{ME}=1.15+\left(0.16^{*} \mathrm{OMDeg}\right)$.

The effect of the dietary inclusion of increasing crude glycerol levels on in- 
vitro digestibility with 48 hours of incubation, degradation rate, effective degradability at passage rate of 2 or $5 \% / \mathrm{h}$, lag time and average $\mathrm{N}-\mathrm{NH}_{3}$, at all times, were analyzed as a completely randomized design using the PROC MIXED (STATISTICAL ANALYSIS SYSTEM, 2012) according with the following mathematical model: $y i j=\mu$ $+\alpha \mathrm{i}+\beta \mathrm{j}+(\alpha \beta) \mathrm{ij}+\varepsilon \mathrm{ij}$, where yij is the observation at run $\mathrm{j}$ given treatment $\mathrm{i} ; \mu$ is the overall mean; $\alpha \mathrm{i}$ is the fixed effect of treatment $\mathrm{i}(0,4,8$ and $12 \%$ glycerol); $\beta \mathrm{j}$ is the aleatory effect of run $\mathrm{j}(1,2,3)$ and $(\alpha \beta) \mathrm{ij}$ is the interaction of treatment $\mathrm{i}$ by run $\mathrm{j}$. Means were compared by the PROC MIXED (STATISTICAL ANALYSIS SYSTEM, 2012) considering linear or quadratic effect of the glycerol level inclusion. Statistical significance was declared at $P$ $\leq 0.05$.

\section{RESULTS AND DISCUSSION}

Substituting corn for crude glycerol had no effect on in-vitro organic matter true digestibility (IVOMTD) or on in-vitro neutral detergent fiber digestibility (IVNDFD) after 48 hours of incubation, with average values of $81.89 \%$ and $60.04 \%$, respectively (Tables 2 and 3 ). These results are consistent with the previous research which shows that feeding levels of glycerol up to $20 \%$ of the total ration does not have any effect on nutrient digestibility or animal performance (DONKIN 2008; KRUEGER et al., 2010). On the other hand, Wang et al. (2009) and Paggi et al. (2004) observed that glycerol decreased the in-vitro organic matter digestibility and in-vitro neutral detergent fiber digestibility in diets.

These results suggest that glycerol can modulate the digestion in a dosedependent manner. In this study, one can concluded that the IVOMTD and IVNDFD were not affected by crude glycerol due to its low level in the diet, allowing optimum rumen fermentation, as growth, adhesion and cellulolytic activity were inhibited when glycerol was included in cultures at high concentration but not at low concentration (ROGER et al., 1992; PAGGI et al. 2004).

Table 2. Effect of crude glycerol inclusion level on the mean values of in-vitro organic matter true digestibility (IVOMTD, \% - with 48 hours of incubation), organic matter degradation parameters ( $a, b, c$, and lag time) and effective degradability of organic matter at passage rates of 2 and $5 \% / \mathrm{h}$

\begin{tabular}{|c|c|c|c|c|c|c|c|}
\hline \multirow{2}{*}{ Variables } & \multicolumn{4}{|c|}{ Crude glycerol inclusion levels (\%) } & \multirow{2}{*}{ SEM } & \multicolumn{2}{|c|}{$\mathrm{P}$ value } \\
\hline & 0 & 4 & 8 & 12 & & Linear & Quadratic \\
\hline IVOMTD, $\%$ & 81.99 & 81.72 & 81.88 & 81.95 & 0.18 & 0.8519 & 0.8793 \\
\hline $\mathrm{a}, \%$ & 66.05 & 64.89 & 65.49 & 65.20 & 0.24 & 0.2463 & 0.3174 \\
\hline $\mathrm{b}, \%$ & 16.54 & 17.44 & 16.67 & 17.09 & 0.33 & 0.2927 & 0.3141 \\
\hline $\mathrm{c}, \% / \mathrm{h}$ & 7.14 & 6.88 & 6.87 & 7.14 & 0.06 & 0.9189 & 0.9718 \\
\hline Lag time, $\mathrm{h}$ & 4.70 & 3.96 & 4.33 & 4.86 & 0.86 & 0.7701 & 0.8328 \\
\hline $\mathrm{ED} 2 \% / \mathrm{h}$ & 77.70 & 77.30 & 77.23 & 77.23 & 0.11 & 0.8037 & 0.8975 \\
\hline ED $5 \% / \mathrm{h}$ & 73.66 & 73.13 & 73.16 & 73.03 & 0.09 & 0.7138 & 0.7989 \\
\hline
\end{tabular}


Table 3. Effect of crude glycerol inclusion level on the mean values of in-vitro neutral detergent fiber digestibility (IVNDFD, \% - with 48 hours of incubation), and neutral detergent fiber degradation parameters (b, c, and lag time) and effective degradability of neutral detergent fiber at passage rates of 2 and $5 \% / \mathrm{h}$

\begin{tabular}{|c|c|c|c|c|c|c|c|}
\hline \multirow{2}{*}{ Variables } & \multicolumn{4}{|c|}{ Crude glycerol inclusion levels (\%) } & \multirow{2}{*}{ SEM } & \multicolumn{2}{|c|}{$\mathrm{P}$ value } \\
\hline & 0 & 4 & 8 & 12 & & Linear & Quadratic \\
\hline IVNDFD, $\%$ & 59.77 & 59.78 & 59.89 & 60.70 & 0.45 & 0.9786 & 0.9621 \\
\hline$b, \%$ & 39.32 & 39.87 & 38.26 & 40.40 & 0.73 & 0.5096 & 0.4068 \\
\hline c, $\% / h$ & 8.88 & 5.64 & 7.73 & 6.95 & 0.00 & 0.0861 & 0.1211 \\
\hline Lag-time, $\mathrm{h}$ & 5.93 & 3.83 & 5.73 & 4.60 & 0.86 & 0.1798 & 0.1924 \\
\hline $\mathrm{ED} 2 \% / \mathrm{h}$ & 50.10 & 49.03 & 49.40 & 50.26 & 0.26 & 0.5107 & 0.6716 \\
\hline $\mathrm{ED} 5 \% / \mathrm{h}$ & 40.23 & 39.23 & 39.73 & 40.30 & 0.27 & 0.5843 & 0.6823 \\
\hline
\end{tabular}

Mean degradation rates of OM and NDF insoluble but potentially degradable fractions (c), expressed in $\% / \mathrm{h}$, for each crude glycerol level were $7.01 \% / \mathrm{h}$ for $\mathrm{OM}$ and $7.30 \% / \mathrm{h}$ for NDF, and were not influenced by the dietary crude glycerol levels.

According to Caton \& Dhuyvetter (1997), effects of energy supplementation on substrate degradation rate are rarely observed, as detected in the present study. However, Wang et al. (2009), evaluating the in-situ digestion kinetics of corn stover, obtained a quadratic effect on the degradation rate of insoluble, but potentially degradable, fractions of DM and NDF with increasing crude glycerol supplementation levels in the diet of steers. These results are different from those obtained in the present study, where the substitution of up to $12 \%$ corn for crude glycerol in dry matter basis had no influence on the degradation of that fraction, possibly due to the better nutritional value of the substrate used and the lower level of crude glycerol in the diet, in agreement with the results observed by Hess et al. (2009).

No effects of the increasing substituting levels of corn for crude glycerol was observed on mean OM and NDF lag time, expressed in hours, with values of $4.46 \mathrm{~h}$ for $\mathrm{OM}$ and $5.02 \mathrm{~h}$ for $\mathrm{NDF}$
(Tables 2 and 3). These results are consistent with Krueger et al. (2010) that evaluated the in-vitro incubation of alfalfa hay and demonstrated that increasing dietary crude glycerol levels did not affect substrate colonization rate $(2.40 \mathrm{~h})$. However, this rate was lower than that found in the present study (5.02h), possibly due to the presence of corn, which may have increased the colonization time of the fiber fraction, and due to the lower level of crude glycerol in the diet, because according with Hess et al. (2009), the NDF lag time tended to decrease linearly $(\mathrm{P}=$ 0.07 ) as crude glycerol increased to $30 \%$ of the in vitro substrate.

Effective degradability (ED) is a measure that integrates ruminal degradation parameters, such as losses due to washing in time zero (a), insoluble but potentially degradable material (b) and its degradation rate (c), with the passage rate of the solid fraction through the gastrointestinal tract. The results obtained for passage rates of $2 \% / \mathrm{h}$ and $5 \% / \mathrm{h}$ were not influenced by substituting corn for crude glycerol levels. Mean values of ED at $2 \% / \mathrm{h}$ were $77.36 \%$ for $\mathrm{OM}$ and $49.70 \%$ for NDF, whereas the results relative to $5 \% / \mathrm{h}$ were $73.25 \%$ for $\mathrm{OM}$ and $39.87 \%$ for NDF (Tables 2 and 3). 
In the present study, we worked with effective degradability (ED) values with solid fraction passage rates of 2 and $5 \% / \mathrm{h}$, because, whereas a low-quality forages present passage rates of approximately $2 \% / \mathrm{h}$, most concentrates mixed with forages have passage rates of about $5 \% / \mathrm{h}$. However, passage rate is closely related to intake, and therefore, it would be more correct to say that the results with passage rates corresponding to low and high intake were analyzed (SHAVER et al., 1986). Passage rates were not influenced with crude glycerol substitution up to $12 \%$. However, Wang et al. (2009), evaluating the in-situ digestion kinetics of corn stover, observed a quadratic effect on ED with a fraction solid passage rate of $2 \% / \mathrm{h}$ for DM and for NDF with increasing crude glycerol supplementation levels in the diet of steers. This was possibly due to the lower nutritional value of corn stover as compared to alfalfa hay, which was used as substrate in the present experiment.

Mean $\mathrm{NH}_{3}-\mathrm{N}$ results, in $\mathrm{mg} / \mathrm{dl}$, and $\mathrm{ME}$, in $\mathrm{MJ} / \mathrm{kg} \mathrm{DM}$, are presented in Table 4 for each crude glycerol dietary level. Neither $\mathrm{NH}_{3}-\mathrm{N}$ nor ME were influenced by corn substitution for crude glycerol, with mean values of $15.69 \mathrm{mg} / \mathrm{dl}$ and $11.95 \mathrm{MJ} / \mathrm{kg} \mathrm{DM}$, respectively.

Table 4. Effect of crude glycerol inclusion level on the mean ammonia nitrogen values $\left(\mathrm{NH}_{3}-\mathrm{N}, \mathrm{mg} / \mathrm{dL}\right)$ and metabolizable energy content $(\mathrm{ME}, \mathrm{MJ} / \mathrm{kg} \mathrm{DM})$

\begin{tabular}{lccccccc}
\hline \multirow{2}{*}{ Variables } & \multicolumn{3}{c}{ Crude glycerol inclusion levels $(\%)$} & \multirow{2}{*}{ SEM } & \multicolumn{2}{c}{ P value } \\
\cline { 2 - 4 } & 0 & 4 & 8 & 12 & & Linear & Quadratic \\
\hline $\mathrm{NH}_{3}-\mathrm{N}, \mathrm{mg} / \mathrm{dL}$ & 16.63 & 15.69 & 14.82 & 15.64 & 0.33 & 0.9385 & 0.8818 \\
$\mathrm{ME}, \mathrm{MJ} / \mathrm{kg} \mathrm{DM}$ & 11.97 & 11.93 & 11.95 & 11.96 & 0.02 & 0.8677 & 0.8970 \\
\hline
\end{tabular}

In in-vitro media, $\mathrm{NH}_{3}-\mathrm{N}$ concentration works as an indicator of protein degradability, because there is no nitrogen absorption or recycling as in the rumen media in-vivo (DETMANN et al., 2011). Because most cellulolytic bacteria require ammonia for growth, low $\mathrm{NH}_{3}-\mathrm{N}$ concentrations may limit microbial activity and thereby, reduce the rate and degree of cell wall digestion. The mean $\mathrm{NH}_{3}-\mathrm{N}$ results obtained in the present study of $15.69 \mathrm{mg} / \mathrm{dl}$ were within the optimal ruminal $\mathrm{NH}_{3}-\mathrm{N}$ range $(12$ to $17 \mathrm{mg} / \mathrm{dl}$, MAPATO et al., 2010; LUNSIN et al., 2012) for rumen ecology, fermentation and optimal microbial growth (ANANTASOOK \& WANAPAT, 2012). These results are consistent with the previous work that shows that feeding glycerol substituting corn or barley grain in the diet does not have any effect on $\mathrm{NH}_{3}-\mathrm{N}$ concentration (ABO EL-NOR et al.; 2010; AVILA et al., 2011).

The energy value of glycerol is approximately equal to the energy contained in corn starch. However, the energy value of glycerol is variable due to the difference between the levels studied, unknown interactions with other dietary components and the proportion of corn and starch in the diet (DONKIN, 2008). Mach et al. (2009) estimated for Holstein young bulls, a metabolizable energy content of crude glycerol (86\% glycerol) of $14.52 \mathrm{MJ} / \mathrm{kg}$ $\mathrm{DM}$, higher than the value observed in this study. But the lack of differences in $\mathrm{ME}$ in the present study suggests that 
corn can be substituted for glycerol without adjustments for the energy content in the diet.

The dietary corn substitution for increasing crude glycerol levels did not affect ammonia nitrogen content, metabolizable energy content, in-vitro digestibility of organic matter and neutral detergent fiber, nor ruminal degradation parameters. However this by-product of biodiesel production may be tested in-vivo as an alternative energy feedstuff in ruminant diets.

\section{FINANCIAL SUPPORT}

The present study received financial support of $\mathrm{CNPq}$ (Conselho Nacional de Desenvolvimento Cientifico e Tecnológico - Brazilian Scientific and Technological Development Council).

\section{REFERENCES}

ABO EL-NOR, S.; ABUGHAZALEHA, A.A.; POTUA, R.B.; HASTINGS, D.; KHATTAB, M.S.A. Effects of differing levels of glycerol on rumen fermentation and bacteria. Animal Feed Science and Technology, v.162, p.99-105, 2010.

ANANTASSOK, N.; WANAPAT, M. Influence of rain tree pod meal supplementation on rice straw based diets using in vitro gas fermentation technique. Asian Australian Journal of Animal Science, v.25, p.325-334, 2012.

AVILA, J.S.; CHAVES, A.V.; HERNANDES-CALVA, M.; BEAUCHEMIN, K.A.; McGINN, S.M.; WANG, Y.; HARSTAD, O.M.; McALLISTER, T.A. Effects of replacing barley grain in feedlot diets with increasing levels of glycerol on in vitro fermentation and methane production. Animal Feed Science and Technology, v.166-167, p.265-268, 2011.

CATON, J.S.; DHUYVETTER, D.V. Influence of energy supplementation on grazing ruminants: requirements and responses. Journal of Animal Science, v.75, p.533-542, 1997.

CHAI, W., UDÉN, P. An alternative oven method combined with different detergent strengths in the analysis of neutral detergent fiber. Animal Feed Science and Technology, v.74, p.281288, 1998.

DETMANN, E.; QUEIROZ, A.C.; ZORZI, K.; MANTOVANI, H.C.; BAYÃO, G.F.V.; GOMES, M.P.C. Degradação in vitro da fibra em detergente neutro de forragem tropical de baixa qualidade em função da suplementação com proteína verdadeira e/ou nitrogênio não-protéico. Revista

Brasileira de Zootecnia, v.40, p.12721279, 2011.

DONKIN, S.S. Glycerol from biodiesel production: the new corn for dairy cattle. Revista Brasileira de Zootecnia, v.37, p.280-286, 2008.

GOERING, H.K.; Van SOEST, P.J. Forage Fiber Analyses (Apparatus, Regents, Procedures, and Some Applications). Agriculture Hand-book No 379. USDA, Washington, DC, 1970.

GOES, R.H.T.B.; TRAMONTINI, R.C.M.; ALMEIRA, R.D.; CARDIN, S.T.; RIBEIRO, J.; OLIVEIRA, L.A.; MOROTTI, F.; BRABES, K.C.S.; OLIVEIRA, E.R. Degradabilidade ruminal da matéria seca e proteína bruta de diferentes subprodutos agroindustriais utilizados na 
alimentação de bovinos. Revista

Brasileira de Saúde e Produção

Animal [online], v.9, p.715-725, 2008.

HESS, B.W.; LAKE, S.L.; GUNTER, S.A. Using glycerin as a supplement for forage-fed ruminants. In:

SYMPOSIUM: RUMINANT

NUTRITION: GLYCERIN AS A FEED FOR RUMINANTS. Journal of Animal Science, v.86, E-Supplement and Journal of Dairy Science, v.91, ESupplement, p.392-393, 2009.

KRUEGER, N.A.; ANDERSON, R.C.; TEDESCHI, L.O.; CALLAWAY, T.L.; EDRINGTON, T.S.; NISBET, D.J.

Evaluation of feeding glycerol on freefatty acid production and fermentation kinetics of mixed ruminal microbes in vitro. Bioresource Technology, v.101, p.8469-8472, 2010.

LUSIN, R.; WANAPAT, M.;

ROWLINSON, P. Effect of cassava hay and rice bran oil supplementation on rumen fermentation, milk yield and milk composition in lactating dairy cows. Asian Australian Journal of Animal Science, v.25, p.1364-1373, 2012.

MACH, N.; BACH, A.; DEVANT, M. Effects of crude glycerin supplementation on performance and meat quality of Holstein bulls fed highconcentrate diets. Journal of Animal Science, v.87, p.632-638, 2009.

MAPATO, C.; WANAPAT, M.; CHERDTHONG, A. Effects of urea treatment of straw and diet level of vegetable oil on lactating dairy cows. Tropical Animal Health and Production, v.42, p.1635-1642, 2010.
McDONALD, J.A. Revised model for estimation of protein degradability in the rumen. Journal of Agriculture Science, v.96, p.251-252, 1981.

McDOUGALL, E.I. Studies on ruminant saliva. 1 . The composition and output of sheep's saliva. Biochemistry Journal, v.43, p.99-110, 1948.

MENKE K.; STEINGASS, H. Estimation of the energetic feed value obtained from chemical analysis and in vitro gas production using rumen fluid. Animal Research Development, v.28, p.7-55, 1988.

OLIVEIRA, L.B.; MUYLAERT , M.S.; ROSA, L.P.; BARATA, M.; LA ROVERE, E.L. Analysis of the sustainability of using wastes in the Brazilian power industry. Renewable and Sustainable Energy Reviews, v.12, p.883-890, 2008.

ØRSKOV, E.R. In situ technique for estimation of forage degradability in ruminants. In: GIVENS, D.I.; OWEN, E.; AXFORD, R.F.E.; OMED H.M. (Eds.) Forage evaluation in ruminant nutrition. London: CABI, 2000. p.113144.

ØRSKOV, E.R.; McDONALD, I. The estimation of protein degradability in the rumen from incubation measurements weighted according to rate of passage. Journal of Agriculture Science, v.92, p.499-503, 1979.

PAGGI, R.A.; FAY, J.P.; FAVERIN, C. In vitro ruminal digestibility of oat hay and cellulolytic activity in the presence of increasing concentrations of shortchain acids and glycerol. Journal of Agricultural Science, v.142, p.89-96, 2004. 
PRATES, E.R. Técnicas de pesquisa em nutrição animal. Porto Alegre: UFRGS, 2007, 414p.

RESTLE, J.; PACHECO, P.S.; COSTA, E,C.; FREITAS, A.K.; VAZ, F.N.; BRONDANI, I.L.; FERNANDES, J.J.R. Apreciação econômica da terminação em confinamento de novilhos Red Angus superjovens abatidos com diferentes pesos. Revista Brasileira de Zootecnia, v.36, p.978986, 2007.

RODRIGUES, F.V.; RONDINA, D. Alternativas de uso de subprodutos da cadeia do biodiesel na alimentação de ruminantes: glicerina bruta. Acta Veterinaria Brasilica, v.7, p.91-99, 2013.

ROGER, V.; FONTY, G.; ANDRE, C.; GOUET, P. Effects of glycerol on the growth, adhesion, and cellulolytic activity of rumen cellulolytic bacteria and anaerobic fungi. Current Microbiology, v.25, p.197-201, 1992.

STATISTICAL ANALYSIS SYSTEM. SAS/STAT User's Guide. Release 9.3 Cary, NC: SAS Institute, 2012.

SHAVER, R.D. NYTES, A.J.; SATTER, L.D.; JORGENSEN, N.A. Influence of amount of feed intake and forage physical form on digestion and passage of prebloom alfalfa hay in dairy cows. Journal of Dairy Science, v.69, p.1545-1559, 1986.
SOARES, C.M.; ÍTAVO, L.C.V.; DIAS, A.M., ARRUDA, E.J.; DELBEN, A.A.S.T.; OLIVEIRA, S.L.; OLIVEIRA, L.C.S. Forage turnip, sunflower, and soybean biodiesel obtained by ethanol synthesis: Production protocols and thermal behavior. Fuel, v.89, p.3725-3729, 2010.

THOMPSON, J.; HE, B.B. Characterization of Crude Glycerol from Biodiesel Production from Multiple Feedstock. Applied Engineering in Agriculture, v.22, p.261-265, 2006.

Van SOEST, P.J.; ROBERTSON, J.B. Analysis of forage and fibrous foods. Ithaca: Cornell University, 1985. 202p.

WANG, C.; LIU, Q.; HUO, W.J.; YANG, W.Z.; DONG, K.H.; HUANG, Y.X.; GUO, G. Effects of glycerol on rumen fermentation, urinary excretion of purine derivatives and feed digestibility in steers. Livestock Science, v.12, p.15-20, 2009.

Data de recebimento: 29/07/2013 Data de aprovação: 21/03/2014 